\title{
HISTORIA HISTORIOGRAFII - JAK DALEKO OD METODOLOGII?
}

\author{
Dariusz DOLAŃSKI \\ Andr zej GILLMEISTER
}

Uniwersytet Zielonogórski

1) Jakie Pan/Pani przyznaje miejsce historiografii w dziedzinie nauk historycznych? W szczególności chcielibyśmy zapytać o relację utrzymywaną przez historię historiografii z historiografią, w tym z historiografią idei, z jednej strony, i metodologią historii, z drugiej. Na czym polega specyficzna tożsamość historii historiografii jako odrębnej dyscypliny badawczej w dziedzinie nauk historycznych?

Wydaje się, że swoistość historii historiografii wynika z jednej strony z możliwości traktowania jej jako odrębnej subdyscypliny historii, ale też jako składowej metodologii historii, historii nauki i historii idei. W każdym z tych aspektów historia historiografii poprzez sformułowanie odrębnego wokabulariusza i kwestionariusza pytań może podejmować inną problematykę: od historii instytucji zajmujących się badaniami historycznymi, poprzez biografistykę, analizę paradygmatów badawczych, relacje między historiografią a literaturą, w końcu kwestie świadomości czy pamięci historycznej, społecznej recepcji wiedzy historycznej itd., a to otwiera zakres zainteresowań historiografii na refleksje z zakresu innych dyscyplin nauki np. politologii, socjologii czy pedagogiki.

2) Czy mógłby/mogłaby Pan/Pani wskazać na 5-10 współczesnych prac z zakresu historii historiografii opublikowanych w językach kongresowych w ciągu ostatnich dziesięciu lat, które mogłyby/powinny zostać włączone do kanonu lektur historyka historiografii w naszym kraju? W naszej intencji lista taka mogłaby również być pomocna w formułowaniu planów wydawniczych dotyczących translacji dzieł z zakresu historii historiografii na język polski. 
- Erhard Wiersing, Geschichte des historischen Denkens: zugleich eine Einführung in die Theorie der Geschichte, Paderborn u.a. 2007.

- Markus Völkel: Geschichtsschreibung. Eine Einführung in globaler Perspektive. Böhlau, Köln u.a. 2006

- Lynn Hunt, Writing history in the global era, New York - London 2014

- The Oxford History of Historical Writing, vol. 1-5, Oxford 2011-2012

3) Jaki rodzaj napięcia dostrzega Pan/Pani między, jak się wydaje, nieredukowalnymi roszczeniami historii historiografii do (a) spełniania kryteriów naukowego dyskursu historiograficznego i (b) objęcia uwagą badawczą całości historii gatunku historiograficznego, od jego pierwszych form w starożytności, poprzez kolejne epoki, po współczesność? W jaki sposób można dzisiaj połączyć teoretycznie, a także praktycznie, naukowość historii historiografii z jej polihistorycznością?

Pytanie czy rzeczywiście takie napięcia są powszechnie dostrzegane i w ogóle mają miejsce. Czy spełnienie kryterium naukowego dyskursu musi stać w sprzeczności z ambicjami objęcia uwagą badawczą całości dyskursu historiograficznego? W tym sensie na podobne trudności musiałaby napotykać historia literatury, która przecież zajmuje się także historiografią, zwłaszcza w odniesieniu do epok dawniejszych. Transtemporalny charakter dociekań historiograficznych należy do silnych stron tego typu rozważań, bo pozwala zauważyć zmiany w postrzeganiu historii i jej roli na przestrzeni wieków. A to z kolei poza oczywistymi korzyściami poznawczymi niesie za sobą znaczenie praktyczne tak dla uprawiania rzemiosła historycznego (i historiograficznego) jak i życia społecznego.

4) Prosimy o wskazanie od jednej do trzech postaci lub ich dzieł z przeszłości polskiej historii historiografii, której/których dorobek dzisiaj niesłusznie pozostaje w cieniu, a zasłuquje na akłualizujące przypomnienie przez samoświadomość historiografii. Prosimy o podanie uzasadnienia wyboru. Jaka przeoczona lekcja z przeszłości naszej dyscypliny mogłaby zostać dzisiaj przyswojona?

Wydaje nam się, że postacią, która zasługuje na przywrócenie do powszechnego obiegu historiograficznego jest Tadeusz Zieliński (1859-1944). Uczony ten łączył w swojej działalności naukowej praktykę nie tylko historyczną, ale także (a może przede wszystkim) filologiczną i religioznawczą. Dla historyka najistotniejsze są jego dokonania w zakresie historii religii antycznych. Dlaczego? Wydaje mi się, że poprzez stworzenie oryginalnej wizji 
doświadczenia religijnego starożytnych Zieliński przekroczył ramy dyskursu historiograficznego. Oryginalny język i polifoniczna forma pisarstwa należą do najwybitniejszych osiągnięć polskiej humanistyki XX wieku. Warto też zauważyć, że Zielińskiego nie można analizować jedynie jako historyka/filologa klasycznego, ale także jako jednego z najoryginalniejszych polskich historiozofów. Dla współczesnej historiografii dorobek tego badacza ma znaczenie wybitne właśnie poprzez przełamanie granic gatunkowych pomiędzy piśmiennictwem naukowym, a eseistycznym i beletrystycznym, a także konsekwentnie budowany obraz badanej rzeczywistości, przez który wyraźnie widać samoświadomość naukowca, a także zaproponowany przez niego nowy sposób uprawiania humanistyki.

5) Prosimy o zaproponowanie nowego kanonu lektur z zakresu polskiej historii historiografii zawierającego do 10 pozycji bibliograficznych. Chodzi nam o listę niewątpliwie wybitnych bądź cieszących się uznaniem dzieł polskich historyków historiografii z ostatnich dwóch stuleci i współczesnych, wyselekcjonowaną (w akcie wyobraźni) w ten sposób, że gdyby lista ta (zbiór dzieł) stała się realnym kanonem kształtującym tożsamość historii historiografii w Polsce i zastąpiła, choćby po części, kanon obecnie realny, pozwoliłaby na ukierunkowanie badań poza dzisiejsze horyzonty naszej dyscypliny. Prosimy o wyobrażenie sobie przyszłości dyscypliny poprzez wyselekcjonowanie innego, niż zwykle wyobrażane, obrazu jej przeszłości.

Wydaje nam się, że polska historia historiografii dopiero stoi przed zadaniem stworzenia kanonu lektur. Już pobieżna analiza choćby sylabusów omawiających uniwersyteckie kursy historiograficzne wyraźnie pokazuje, że taki kanon nie istnieje. A jest to miejsce, w którym powinien być widoczny najbardziej.

6) Jakie zadania dydaktyczne stoją przed uniwersyteckim kursem z zakresu historii historiografii? Jakie jest miejsce historii historiografii w kształceniu historyka oraz w nabywaniu ogólnego wykształcenia humanistycznego?

Trudno wyobrazić sobie dzisiaj studia historyczne bez wyodrębnionego kursu historii historiografii lub chociaż połączonego z metodologią historii. Wprowadzony przez Ustawę Prawo o szkolnictwie wyższym podział na kształcenie ogólnoakademickie i praktyczne, w której za cel tego pierwszego przyjęto przygotowanie do prowadzenia badań naukowych wydaje się wręcz wskazywać miejsce historii historiografii w kształceniu akademickim jako przedmiotu ukazującego rozwój nauki historycznej poprzez pryzmat paradygmatów badawczych i kształtowanie krytycznej postawy wobec tekstu historiograficznego. 